\title{
Priority Areas of Education Development in the Conditions of Digital Transformation and the Information Society
}

\author{
Moiseev V.V. ${ }^{1,}$ Komarova O.A. ${ }^{1}$ Seliverstov Yu.I. ${ }^{1}$ Shepherd T.A. ${ }^{2}$ \\ ${ }^{1}$ Belgorod State Technological University. V.G. Shukhov, Belgorod, Russia \\ ${ }^{2}$ Tula branch of the Russian Academy national economy and public service, Tula, Russia \\ *Corresponding author. Email: yliu@nufe.edu.cn
}

\begin{abstract}
The rapid development of digital technologies has led to the emergence of a new milestone in human civilization, the digital era, which is characterized by the appearance of virtual human extensions, that is, the Internet, as well as various gadgets and devices that make it possible to constantly be online and combine existence in the real physical world with "life" in the digital (virtual) universe. The formation of a new social reality that arises as a result of complementing reality with a virtual (digital) component, where online and offline being are connected together, is the main challenge of our time and determines the direction of actual transformations in almost all spheres of human life.

It is becoming impossible to live actively outside the development and quality use of the potential capabilities of modern information technologies, especially in the field of educational services. Thus, a special function of education is crystallized: to teach a person to use information resources, to form appropriate competencies, to educate the ability to live in a new information space. For its implementation, modern education should significantly change its own contours, adopt and move to a new philosophical development paradigm, the information. Informational reloads determine the essence of the reform of modern education. In connection with the above, the article is devoted to the substantiation of priority areas for the development of education in the context of digital transformation and the information society.
\end{abstract}

Keywords: information society, informatization, digital transformation, education, educational environment,

information competence

\section{INTRODUCTION}

Since the inception of civilization, education has always been a center of concentration of social and individual interests. And this is natural. After all, it is through education and upbringing that a person enters the social context. An extraordinary attention to the problems of education is due to such modern trends in world social development as the digital transformation and the information revolution, the intensive change of traditional ideas about the world and the place of man in it, a rapid increase in knowledge and information, the transformation of the educational sphere into a productive sector of the economy along with material production.

It is obvious today that education should ensure the formation of the individual in accordance with the challenges of the time. And since one of the main ones is the challenge of the modern information space, the educational sphere should form the competencies of the person, which would ensure a comfortable sense of self and work in the information space. The need to search for the principles of lifelong education under the influence of the information space becomes acute. Mankind has always been in the information space, but its current state, determined by the rapid development of information technology, carries significant challenges to all spheres of life, and especially to the educational sphere.

\section{METHODS}

The purpose of the study is to justify the priority areas for the development of education in the context of digital transformation and the information society. To achieve this goal, the following tasks were set and solved:

- to formulate the starting points of the educational paradigm in the context of digital transformation;

- to substantiate the goals, objectives and principles of lifelong education as the basis for the formation of personality, adapted to constant changes in the external environment; 
- to analyze the informatization of education as a mechanism ensuring the formation of a new education paradigm.

Theoretical, methodological and methodological aspects of the modernization of education in the context of digital transformation and informatization of society received significant development in the works of S.S. Grinkevich, I.V. Dvoretskaya, K.K. Kolin, I.R. Protsiva, A.Ju. Uvarov, I.D. Frumin $[1 ; 2 ; 3]$. These authors indicate the feasibility of accelerating the development of the educational sector in the context of the intellectualization of all spheres of society and increasing the information saturation of labor processes.

The specifics of the influence of the processes of digital transformation and informatization of society on the development of education is analyzed in the works of V.L. Inozemtsev, N. Kaminina, N.P. Petrova, Ju.V. Sharonin and others $[4 ; 5 ; 6 ; 7]$, which substantiate the role of information as a fundamental factor in social development and determines the external and internal factors of transformation processes in the field of education.

Special studies of the formation of information competence in the education system are described in the works of V.F. Burmakina, O.N. Ionova, M. Zelman, D.S. Ermakova, N.N. Korovkina, E.V. Petrova, I.N. Falina, K.K. Khenera, A.V. Khutorsky [8-14] and others, which reveal the essence of information competence, the conditions for its formation and development.

Scientific interest in studying the problems of the formation of information culture was shown by such scientists as N.G. Vokhryshev, K.K. Kolin, S.M. Oleneva, B.A. Semenovker, E.P. Semenyuk [3; 15-18] and others. In their works, they substantiate the desirability of forming an information culture of the individual in the learning process at all levels of the education system.

At the same time, the problem of developing priority areas for the development of education in the context of digital transformation and informatization of society remains poorly understood. This is manifested, in particular, in the absence of an integral theoretical and methodological substantiation of goals, objectives, principles of the transformation of the educational paradigm in the conditions of the transformation of knowledge and information into a key economic resource.

\section{RESULTS}

In the conditions of the development of the information society based on reason, knowledge, intellectual abilities, the speed of reproduction of information, the speed and volume of information flows are accelerating. Currently, information has become a resource, and information technology - a means of increasing productivity and labor efficiency. Under such circumstances, society puts forward fundamentally new requirements for the education system, in particular, the need arose to establish a new educational paradigm based on a change in the fundamental concepts of man and his development through education. Today, the requirement for students regarding the assimilation of all knowledge accumulated by humanity is losing relevance. The first place is the requirement for a person to have the ability to learn, that is, to solve problems in the field of educational activity, to realize educational goals through his own educational trajectory. The new education paradigm should be based on the following starting points: - education is called upon to form an independent (critical) type of personality thinking based on training in working with various types of information, its processing and analysis skills;

- education should reorient from the traditional principle of the formation of knowledge, skills and abilities to the principle of the formation of competence of a student (student);

- education should build lifelong learning skills through the use of modern information technologies.

In the information society, it is necessary to carry out fundamental changes in the educational process, improve the quality of educational services, popularize higher education among the population, bring educational standards in line with the requirements of digital transformation [1, p. 22].

The fourth industrial revolution imposed qualitatively new demands for employees: a high level of mathematical literacy; thorough scientific and humanitarian training; strong knowledge, skills and abilities in the field of technology (project thinking, digital literacy, algorithmic thinking, critical thinking) [2, p. 22]. Such requirements for the qualifications of employees are determined by objective production reality: the share of enterprises in the business sector using broadband Internet has grown from $63.8 \%$ in 2013 to $80.8 \%$ in 2017 , and cloud services from $11.0 \%$ in 2013 up to $22.6 \%$ in 2017 , electronic data exchange between their and external information systems from $24.1 \%$ to $62.2 \%$, respectively. The dynamics of similar indicators in organizations of the social sphere for the same periods amounted, respectively, from $49.2 \%$ to $83.5 \%$, from $12.0 \%$ to $24.4 \%$, from $49.8 \%$ to $62.6 \%$ [ 19 , p. $14]$.

In the context of the growing role of information and digital technologies in social development, the information saturation of the external environment of human life is dynamically increasing. Under such circumstances, the task of education becomes to teach a person to live in a turbulent information stream, creating the conditions for his continuous development. In connection with this, the basic principle of education in the context of digital transformation and the development of the information society is the principle of continuity, which means that the educational potential of a person must grow throughout her life. The relevance of the development of education on the principle of continuity is due to the objective need for updating knowledge.

Once every 12 years, UNESCO holds international conferences on adult education. The first Conference was held in Elsinore (Denmark) in 1949, subsequent conferences were held in Montreal (Canada) 1960; Tokyo (Japan) 1972, Paris (France) 1985, Hamburg (Germany) 
1997, Belen (Brazil) 2009. In 1998, the Russian Adult Education Association was established in St. Petersburg. In 2001, a tripartite agreement on cooperation in adult education was signed between the UNESCO Institute for Education (Hamburg), the Russian Adult Education Association and the Russian Commission for UNESCO [20].

The goal of continuing education in Russia should be the training of specialists of a new quality, adequate to the requirements of the information society, mobile in the face of increasing globalization processes in the global economy, capable of continuous professional development and work in a changing external environment.

Realization of this goal requires solving the following tasks:

- development of a system of additional educational services that ensure the implementation of the principle of "education throughout life";

- forecasting needs in the field of continuing education based on the study of the labor market and educational services;

- creation of a modern material-technical, educationalmethodical and information base for the development of continuing education.

The goals and objectives of continuing education determine the appropriateness of its development according to the following principles:

- systemic principle: lifelong education should be designed, function and develop as a system consisting of interconnected and mutually agreed elements;

- principle of science: the content of instruction in the system of continuing education should be formed on the basis of scientific knowledge corresponding to the latest achievements of science and technology;

- the principle of pragmatic orientation: the content of training should be aimed at providing pupils (students) with knowledge and skills that meet current and future needs of production;

- principle of information: the functioning of the continuing education system should be based on modern information and communication technologies;

- the principle of individualization and differentiation of training - providing targeted selection of forms and methods of training for each person, which allows you to create an individual educational path and the corresponding differentiated training plan;

- mobility principle: training programs, forms of knowledge control in domestic educational institutions should be unified with similar programs and forms of knowledge control in leading foreign educational institutions.

The implementation of the principles of continuing education will solve the problem of human preparedness for life in the information society.

The main mechanism ensuring the formation of a new paradigm of education is the informatization of education. The latter is, firstly, the process of providing the educational sector with the methodology and practice of developing and making optimal use of modern information and communication technologies; secondly, a set of measures aimed at improving pedagogical processes through the computerization of educational institutions and the introduction of information technologies in the educational sphere in order to ensure that information competence and the information culture of individuals correspond to the modern requirements and needs of the information society.

Considerable attention is being paid to the development of education through the introduction of information technology on the part of state authorities and the scientific and pedagogical community. This is evidenced by the regulatory and legislative framework in this area. In particular, the priorities of state policy in the field of informatization of society are identified:

- by the Decrees of the President of the Russian Federation:

- dated May 7, 2018, No. 204 "On National Goals and Strategic Tasks of the Development of the Russian Federation for the Period until 2024";

- dated May 9, 2017, No. 203 "On the Strategy for the Development of the Information Society in the Russian Federation for 2017-2030";

- dated December 1, 2016, No. 642 "On the Strategy of scientific and technological development of the Russian Federation";

- dated December 5, 2016, No. 646 "On approval of the Doctrine of Information Security of the Russian Federation";

- be the main activities of the Government of the Russian Federation for the period up to 2024, approved by the Chairman of the Government of the Russian Federation on September 29, 2018;

- by the concept of long-term socio-economic development of the Russian Federation for the period until 2020, approved by order of the Government of the Russian Federation of November 17, 2008, No. 1662-r,

- by the strategy of innovative development of the Russian Federation for the period until 2020, approved by order of the Government of the Russian Federation of December 8, 2011, No. 2227-r.

In addition, in 2014 the state program of the Russian Federation "Information Society" was approved, consisting of the following subprograms:

Subprogramme 1. "Information and telecommunication infrastructure of the information society and services provided on its basis";

Subprogramme 2. "Information Environment";

Subprogramme 3. "Security in the information society"; Subprogramme 4. "Information State" [21].

It is advisable to single out the following as the main goals of informatization of the educational sphere:

- the formation of information culture and information competence of trainees (students) in order to ensure their rapid professional adaptation in the information society; - improving the quality of education by improving the content, methods, and forms of training based on the latest information technologies; 
- accelerating the integration of the domestic education system in the European and world educational space;

- increasing the economic, scientific, technical and cultural potential of the country due to the growth of the educational level of the population.

- The main tasks of informatization of education are:

- the formation of trainees (students) willingness to use information technology in their future professional activities;

- the provision in the upper grades of the comprehensive school of theoretical knowledge in the field of computer science and information technology, which in the future will form the basis for the formation of practical skills in using the latter;

- the provision in vocational schools of knowledge and skills in the field of information technology that will contribute to the professional adaptation of graduates;

- development of a system of advanced training and retraining of personnel based on information technologies with the aim of increasing their mobility and competitiveness.

Based on these needs, goals and objectives, the priority areas of informatization of domestic education are:

- improving the level of computerization of educational institutions, creating conditions for personal access to computer facilities at all levels of education;

- advanced training and retraining of teachers in the field of information technology in order to increase their information competence;

- development of a new generation of training complexes based on the use of information technology;

- creating conditions for the use of hardware and software of information technology in order to ensure the visibility of educational material, its systematization and quality control of knowledge;

- creation and development of domestic information and educational networks and the organization of connecting educational institutions to them;

- development and implementation of government programs aimed at the development of information technology training, the creation of a unified educational information environment;

- development of an open education system.

The implementation of these areas of education informatization will contribute to the formation of information competence and information culture of all participants in the educational process.

In modern theory and practice, there are two approaches to understanding the essence of the concept of information competence. Supporters of the first approach, such as O.N. Ionova, V.F. Burmakina, M. Zelman, I.N. Falina, K.K. Khener et al. consider information competence in the narrow sense, focusing on the ability to use various technical means of information processing and actually equating information competence with computer literacy $[8,9,13]$. Representatives of the second approach (D.S. Ermakov, N.N. Korovkina, E.V. Petrova, S.V. Trishina, A.V. Khutorskoy $[10-12 ; 14]$ and others) consider information competence in a broad sense and put at the same time information and the ability to work with it at the forefront. So, D.S. Ermakov defines information competence as "meaningful mastery of theoretical knowledge, skills, ways of thinking, values that allow you to realize yourself in specific types of information activities; ability, readiness and experience of independent informational activity "[10]. E.V. Petrova points out that information competence is the ability of a person to comprehend the realities of the information society by a person, a means to realize all the opportunities provided by it. She believes that to train a specialist whose qualifications would meet the ever-changing requirements of society, it is necessary to use all the educational opportunities provided by modern information and communication technologies [12]. In our opinion, information competence is, first of all, the willingness to use knowledge and skills in the field of information and communication technologies in practice in order to quickly find the necessary information, process it, organize, analyze and evaluate it.

Numerous works of scientists bring to light problems of information culture formation, in particular works by N.G. Vokhryshev, K.K. Kolin, S.M. Oleneva, A.I. Rakitov, B.A. Semenovker, E.P. Semenyuk and others An analysis of the scientific works of these authors made it possible to distinguish three approaches to determining the essence of information culture, in particular: the historical approach, according to which information culture is considered from the standpoint of its genesis as historical and social conditioning $[3$, p. $12 ; 18$, p. $15 ;]$; a technological approach in which information culture is a methodological apparatus for operating social information, a measure of excellence in operating with any information [16, p. 141; 17, p. 3]; a philosophical approach that defines information culture as a way of informational regulation of social contradictions [5, p. 52]. All of these authors focus on the advisability of forming an information culture of the individual in the learning process at all levels of the education system.

Therefore, the formation of an informational culture of a person in the learning process involves the transfer of knowledge, skills and abilities to find the necessary information, its understanding and creative use, the formation of a creative attitude to professional activity based on the use of the existing variety of information sources and information technologies. An important component of information culture is the conscious motivation of the individual, firstly, to develop the skills of information activities and information communication based on information and telecommunication technologies; secondly, the satisfaction of individual information needs based on information technology and modern computer tools.

Thus, the emergence and intensive development of information computer technologies requires an adequate response of the education system to them. The education system as a social institution designed to prepare people for life through the transfer of knowledge, skills, norms of activity, cultural values, must be transformed in 
accordance with the requirements of the information society and digital transformations.

\section{DISCUSSION}

Study of the problems of the development of education at the beginning of the $21 \mathrm{st}$ century. acquires special significance for the further development of society. This is due to a change in the place and role of the individual in the system of social progress, the activation of intelligence as the main resource of social development, the introduction of the latest technologies in human activity caused by the information revolution. A person as a person with its worldview and thinking, feelings and emotions, knowledge is becoming more and more noticeably the main subject of social transformations. Intelligence is affirmed as the main strategic development resource. Digital transformation and the intellectualization of work bring with them new and modern technologies that replace traditional activities. Actually, the information society forms new, increasingly responsible challenges for people. Preparing for life in this society, a person conducts an intensive search for answers both regarding the contours of future reality, as well as his own status, behavior and activities. Historically determined is the fact of the search for answers not only in the system of extra-scientific (mythological, religious, etc.) experience, but, above all, in the system of new rationality, in the system of science, culture and education.

The thinking elite of modern society is trying to penetrate the structure of transformations, to embrace their meaning and certainty, to formulate offers that would allow us to keep pace with the times and at the same time, be one step ahead of it. Of particular importance are theoretical searches in the field of modernization of education in the conditions of transformation of the information space and the development of the information and communication environment of education, and this is understandable. Education is that unique institution of personality socialization, which provides a systematic and targeted formation of the latter in accordance with the achievements of science, culture and practice, modern and promising social and individual needs. In connection with the mentioned, the role of the educational sphere, which provides public education and training, is being actualized.

\section{CONCLUSION}

The reform of Russian education in the development of the information society initiates the development of new pedagogical information technologies, the computerization of educational processes, the integration of traditional teaching materials and manuals with their electronic versions. The main task of education is to provide skills in working with information, transforming it into knowledge. The leading ideological principle of education should be the principle of communication, which suggests that educational institutions are called upon to form the competence of students in the field of operating information and converting it into knowledge. The task of modern education is the creation of information technologies for teaching any discipline, the modern equipment of the educational process, the development and implementation of proprietary teaching methods using modern information tools.

The key principle of education in the context of digital transformation and the development of the information society is the principle of continuity, which means the expediency of the growth of the educational potential of a person throughout life. The main goal of continuing education is to prepare a person for life in a dynamically changing environment (political, economic, cultural, social). Realization of this goal requires the solution of certain tasks: the study of the labor market and educational services with the aim of forecasting needs in the field of continuing education; creation of a modern resource base for the development of continuing education; development of a system of additional educational services that ensure the implementation of the principle of continuing education. Achieving the goals and objectives of continuing education necessitates its development in accordance with the following principles: the principle of consistency; the principle of science; the principle of pragmatic orientation; the principle of individualization and differentiation of education; the principle of mobility. A necessary condition and the main mechanism for the formation of a new educational paradigm in the context of digital transformation is the informatization of education, aimed at:

the formation of information culture and information competence of trainees (students) in order to ensure their rapid professional adaptation in the information society; improving the quality of education by improving the content, methods and forms of training based on the latest information technologies;

accelerating the integration of the domestic education system in the European and world educational space;

increasing the economic, scientific, technical and cultural potential of the country due to the growth of the educational level of the population.

\section{ACKNOWLEDGMENT}

The reported study was funded by RFBR, project number 19-29-07024.

\section{REFERENCES}

[1] S. S. Grinkevich, Domínanti rozvitku trudovogo potentsíalu v kontekstí stanovlennya ínfrmatsíynogo suspíl'stva v Ukraïní, Yekonomíchniy chasopis KHKHÍ. 2012. No. 7-8. S. 34-37. URL: http://soskin.info/ea/2012/7-8/zmist.html. 
[13] K.K. Khener, Informatsionno-

[2] Trudnosti i perspektivy tsifrovoy transformatsii obrazovaniya, Nats. issled. un-t «Vysshaya shkola ekonomiki», In-t obrazovaniya. M.: Izd. dom Vysshey shkoly ekonomiki, 2019. 343 s.

[3] K.K. Kolin Global'nyye problemy informatizatsii obshchestva, Vestnik vysshey shkoly. 2000. No. 6. S. 12-16.

[4] V. L. Inozemtsev, Sovremennoye postindustrial'noye obshchestvo: priroda, protivorechiya, perspektivy. M.: Logos, 2000. 304 s.

[5] I. R. Kamynina, Tsifrovyye tekhnologii v vysshem obrazovanii: sovremennyy podkhod $\mathrm{k}$ podgotovke kadrov, Vestnik inzhenernykh izyskaniy. URL: http://izyskateli.info/2019/08/tsifrovye-tehnologii-vvysshem-obrazovanii-sovremennyj-podhod-kpodgotovke-kadrov/

[6] N. P. Petrova, Tsifrovizatsiya i tsifrovyye tekhnologii V obrazovanii, Mir nauki, kul'tury, obrazovaniya, 2019. No. 5(78). S. 353-355.

[7] Yu. V. Sharonin, Tsifrovyye tekhnologii v vysshem i professional'nom obrazovanii: ot lichnosti oriyentirovannoy smart-didaktiki $\mathrm{k}$ blokcheynu $\mathrm{V}$ tselevoy podgotovke spetsialistov, Sovremennyye problemy nauki i obrazovaniya. 2019.No. 1. - URL: https://science-education.ru/ru/article/view?id=28507

[8] V. F. Burmakina, Informatsionnokommunikatsionno-tekhnologicheskaya

kompetentnost': metodicheskoye rukovodstvo dlya podgotovki k testirovaniyu uchiteley, M. Zelman, I. N. Falina. M.: NFPK, 2007. 56 s.

[9] O. N. Ionova, Formirovaniye informatsionnoy kompetentnosti vzroslykh $\mathrm{v}$ protsesse dopolnitel'nogo obrazovaniya: avtoref. dis. ... kand. ped. nauk. V. Novgorod: [b. i.], 2007. 20 s.

[10] D. S. Yermakov, Informatsionnaya kompetentnost': polucheniye znaniy iz informatsii, Otkrytoye obrazovaniye. 2011. No. 1. S. 4-8.

[11] N. N. Korovkina, Informatsionnaya kompetentnost' uchashchikhsya obshcheobrazovatel'noy shkoly, Sayt «Festival' pedagogicheskikh idey. Otkrytyy urok». URL: https://urok.1sept.ru/

[12] Ye. V. Petrova, Informatsionnaya kompetentnost' v obrazovanii kak zalog uspeshnoy adaptatsii cheloveka $\mathrm{v}$ informatsionnom obshchestve, Informatsionnoye obshchestvo. 2012. No. 2. S. 37-43. kommunikatsionnaya kompetentnost' uchitelya: struktura, trebovaniya i sistema izmereniya, Informatika i obrazovaniye. 2004. No. 12. S. 5-9.

A. V. Khutorskoy, Tekhnologiya proyektirovaniya klyuchevykh i predmetnykh kompetentsiy, Internetzhurnal «Eydos». 2005. 12 dekabrya. URL: http://www.eidos.ru/journal/2005/1212.htm

[14] M. G. Vokhrysheva, Formirovaniye nauki ob informatsionnoy kul'ture, Problemy informatsionnoy kul'tury: Sb. statey. M.: Magnitogorsk, 2007. Vyp. 6. Metodologiya i organizatsiya informatsionnokul'turologicheskikh issledovaniy. S. 48-63.

[15] S. M. Oleneva, Informatsionnaya kul'tura obshchestva, Novosibirsk: NGAEiU, 2011. 356 s.

[16] E. P. Semenyuk, Tekhnologicheskiy etap nauchno-tekhnicheskoy revolyutsii i informatika, NTI. Ser. 1. 2005. No. 1. S. 1-9.

[17] B. A. Semenovker, Informatsionnaya kul'tura: ot papirusa do kompaktnykh opticheskikh diskov, Bibliografiya. 1994. No. 1. S. 12-20.

[18] Indikatory tsifrovoy ekonomiki: 2019 : statisticheskiy sbornik, G. I. Abdrakhmanova, K.O. Vishnevskiy, L. M. Gokhberg i dr.; Nats. issled. un-t «Vysshaya shkola ekonomiki». M.: NIU VSHCHE, 2019. $248 \mathrm{~s}$

[19] L.YA. Khoron'ko, T.A. Tskvitariya, I.V. Manukyan Obrazovaniye vzroslykh v kontekste programm YUNESKO, Internet-zhurnal «Mir nauki». 2016. Tom 4. No. 6. URL: http://mir-nauki.com/PDF/90PDMN616.pdf

[20] Postanovleniye Pravitel'stva RF ot 15.04.2014 No. 313 (red. ot 30.11.2019) «Ob utverzhdenii gosudarstvennoy programmy Rossiyskoy Federatsii «Informatsionnoye obshchestvo». URL: http://www.consultant.ru/document/cons_doc_LAW_1 62184/ 